\title{
RELATIVE STUDY OF SEISMIC ANALYSIS BETWEEN FLAT SLAB AND GRID SLAB OF RCC STRUCTURES WITH DIFFERENT MASONRY INFILLS IN TWO DIFFERENT ZONES
}

\author{
Mohammed Fatir ${ }^{1}$, M.H.Kolhar ${ }^{2}$, AnjumAlgur ${ }^{3}$ \\ ${ }^{1,2,3}$ Research Center, Department of Civil Engineering, Secab Institute of Engineering and Technology, Vijayapur, \\ Karnataka, India \\ Imdfatirserikar@gmail.com, 2mahikolhar@yahoo.in, 3mainu7757@gmail.com
}

\begin{abstract}
Recently there has been a considerable increase in the number of tall buildings, both residential and commercial, and modern trend is towards taller structures, Flat slab is most widely used systems in reinforced concrete construction in offices, residential and industrial buildings in many parts of the world. The flat plate system, in which columns directly support floor slabs without beams. To improve the performance of building having flat slabs under seismic loading, provision of flat slab with drop is proposed. The object of the present work is to compare the behaviour of multi-storey buildings having flat slabs with drops with that of conventional beam column framing so called grid slab system under linear dynamic analysis (Response spectrum analysis) with different masonry infills i.e. shear wall and concrete bracing in two different zones i.e. zone III and zone IV with medium soil type conditions. Software ETABS is used for this purpose. The parameters study are Time Period, Base shear, Displacements and Story Drift. And it is found that the structure with infills shows better performance in comparison with structures without infills. In addition to this the structure with shear wall reduced max displacement and storey drift and time period of different types of structures in both the zone in comparison with structure with concrete bracing.
\end{abstract}

Keywords: Flat Slab with and Without Drop, Grid Slab, Response Spectrum Method, Shear Wall, Concrete X-type Bracing, Time Period, Base shear, Displacements and Story Drift

\section{INTRODUCTION}

The rapid growth of the urban population and scarcity of space have considerable influence the development of vertical growth consisting of low rise, medium rise and high rise buildings. Generally reinforced concrete is the major construction material used for these buildings and it has been used for building construction since 19th century. Reinforced concrete structures are always subjected to gravity and lateral loads, that is live load, dead load, superimposed load, and lateral loads are such as seismic load and wind load. Previously buildings were designed for only gravity loads that may not have resistance to lateral loads. In reinforced concrete structures horizontal loads are first which will increase proportionally with increase floor height of the buildings as a result lateral loads are higher in the top storey compare to the bottom storey due to which building tends to act as cantilever and that forces develop high stresses, produce sway movement leads to severe damages and hence at last failure of buildings. The failure of buildings occurs mostly in the seismic prone areas where the structures are not well designed for earthquake load and wind loads. Therefore, it is very much necessary to design the structures to have sufficient stiffness to resist the lateral forces. For this purpose an earthquake resistant design of reinforced concrete structures is a current part of research across the world. The main purpose of this earthquake resistant design of reinforced concrete research is to design structural members of building like column, beam, and slab to withstand against the dynamic forces and make sure the building should be safe and stiff under effect of worst condition. Usually in reinforced concrete buildings to resist against lateral load, sometimes a structural members are modified that may be column, beam and slab, but in this project is more concern about slabs. Generally there is so many types of slab but here will discuss about two different type of slabs that is flat slab and grid slab. To assure more strength of reinforced concrete structures commonly shear wall and bracing is also used because shear wall and bracing are highly efficient method of resisting horizontal forces in a reinforced concrete structures.

\subsection{Flat Slab}

Commonly the reinforced concrete slab is supported directly by beams and beams is supported by columns this system is known as slab-beam construction. In slab-beam construction, beam decreases the available net clear floor height, hence in structures like offices, warehouses and public halls sometimes due to aesthetic view beams are not provided thus slabs are directly placed on columns. So these type of construction of slabs directly supported by columns are known as Flat slab as shown in figure below. 


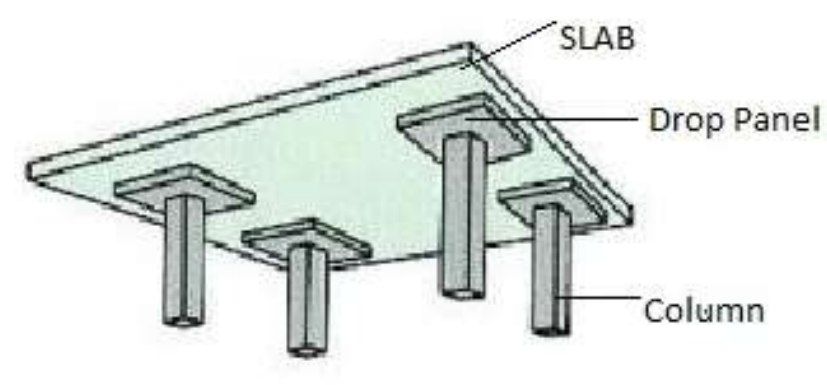

Fig 1:-Flat Slab

In reinforced concrete buildings flats slab become one of the most widely used floor systems in structures like hotels, hospital, shopping mall, and multi-storey commercial structures. Because it is very easy in construction, increases the floor height, reduces the dead load of structure as beams is avoided, flexible arrangement of column as per the architects and clients choice for their aesthetic appearance, and at last construction is fast with economic advantage. But the main disadvantage are as it does not include proper rigidity at the joint of slab column rather than beam column joint, also shear concentration is very much high around the column due to punching of through the slab, and it possess very large deflection with addition to this flat slab has some more disadvantage that is lack of resistance to horizontal loads such as wind and earthquakes. Hence some special features like bracings and shear wall should be provided if flat sab are to be used in high rise buildings and also in earthquake zones. The flat slab sometimes are of without drop and column head, with drop and column head, and drop without column head and column head without drop as figures shown below. They are types of flat slab:
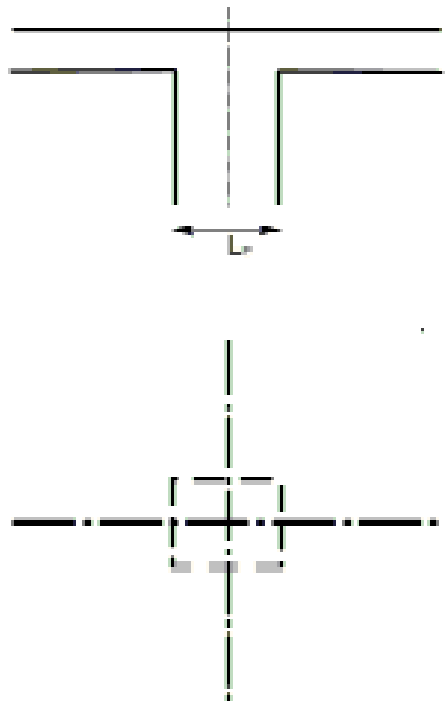

Fig 2:-Flat slab
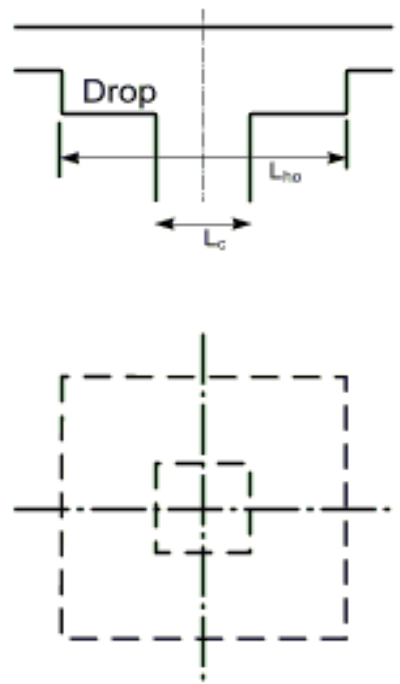

Fig 3:- Flat slab with drop panel
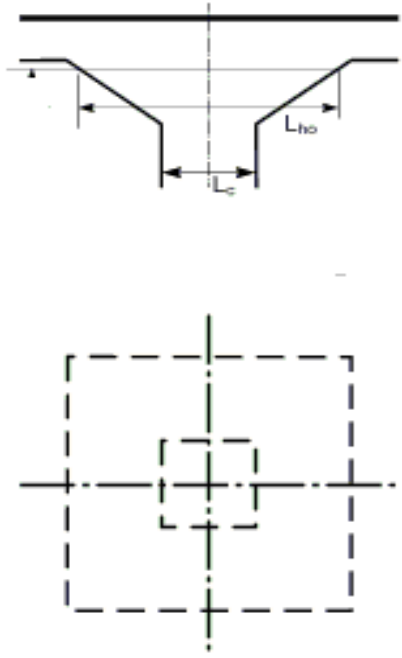

Fig 4:- Flat slab with column head

\subsection{Drop}

The drop which is provided sandwich between slab and column usually rectangular in plan. The thickness should be at least 1.25 times of the main slab thickness but not more than 1.5 times. This over thickness reduces deflection and also provide resistance against punching shear and it also assists in reducing the requirement of steel for the negative moment at the supports. The enlargement of width on both side of column from its centre line is called drop width, and this width should not less than $1 / 3$ th of the panel length in that direction.

\subsection{Column Head}

The column head provided just below the slab that is at the top of column and sometimes it is provided with drop also, main purpose of column head is to increase the resistance capacity of the slab against punching shear hence it increases the rigidity of the slab. The height of column head should be more than $15 \mathrm{~cm}$ and it is of circular cone or pyramid of vertical angle of $90 \mathrm{o}$ 


\subsection{Grid Slab}

Grid floor consist of intersecting beams at consistent intervals in both direction and it's monolithically slab. Commonly this floor system is of rectangular or square in shape for good aesthetic appearance. Spacing of beams usually kept the same but different in direction that is sometimes beams are made to intersect at diagonals for architecture purpose. This floor system is inherently strong..

\subsection{Shear Wall}

Continuous vertical walls of concrete or masonry may contribute both architecturally as partitions as well as structurally to withstand against gravity and horizontal loading. This shear wall in structures are entirely responsible for the resistance to the lateral loads. Because these walls are more stiffer horizontally rather than rigid frames, and it is economical up to 35 stories. Shear wall is well suited in hotels and residential building where repetitive planning of floor by floor allows wall to act vertically continuous to serve as excellent auditory and fire resistance between rooms and apartments. It may be of different shape based on the architecture requirement of the building such as L, T, I or U-shaped to better increase their flexural stiffness

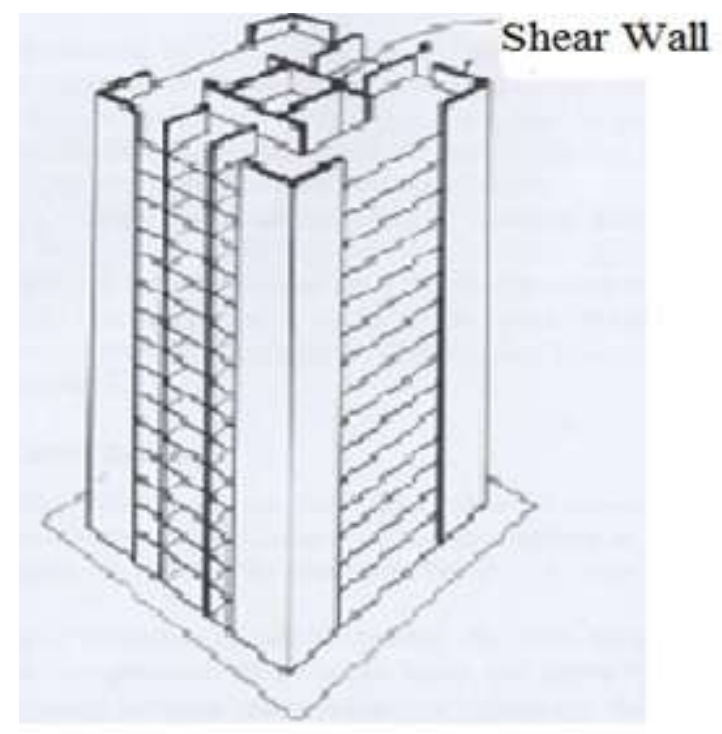

Fig 5:-Shear Wall

\subsection{Bracing}

Bracing is usually provided in the structures to resist against lateral forces by transferring the horizontal loads down to the ground thus it also prevent sway of the structure. Bracing may be of concrete and steel materials based up on the structural need one can select. Bracing are of two types one is concentric bracing system and other is eccentric bracing system. In concentric bracing it increases the horizontal stiffness of the structure by decreasing storey drift thus increases the natural frequency where as in eccentric bracing it reduces lateral stiffness by improving the energy dissipation capacity. Commonly bracing are provided in vertical planes between the columns. Bracing are of different shape like X, K, V, Inverted V, Diagonal types as shown in figure below.

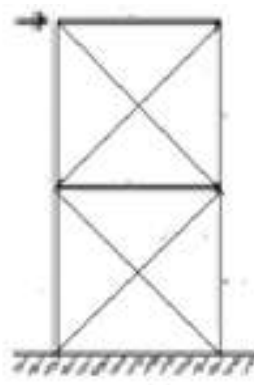

X-type

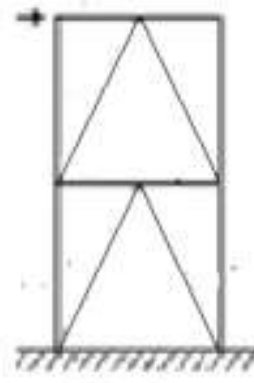

Inverted V-type

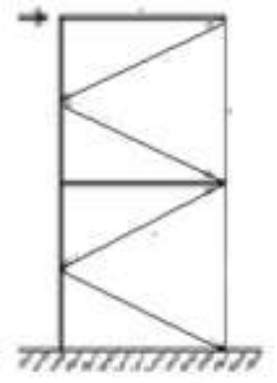

K-type
Fig 6:-Type of Bracing

\subsection{Objectives}

The main purpose of this analysis is to study the comparison between grid slab and flat slab with and without drop structures for various seismic parameters such as

- To study the maximum displacement of different types of slab structure for zone II and zone III with and without infills.

- Comparison of maximum time period of grid slab and flat slab with drop in zone IV with and without infills.

- Comparative study of base shear of grid slab and flat slab with and without drop under seismic zone III and zone IV with and without infills.

- To study the maximum storey drift for different types of slab structure for zone III and zone IV with and without infills,

- Comparative study of the effect of infills such as shear wall and bracing on grid and flat slab with and without drop.

\section{MODELLING AND ANALYSIS}

The study is done on 18 different model of a 15 storey building are modelled. The building plan has 7 bays in $\mathrm{X}$ and $\mathrm{Y}$ direction with spacing of 5 meters in each direction. The height of each floor is $3.0 \mathrm{~m}$ thus total height of the building is $30 \mathrm{~m}$.

The different components of grid slab structure and flat slab structure with different masonry are as follows

- Grade of concrete M40

- Grade of steel Fe-500

- Column size of the structure is of $600 \mathrm{mmx} 900 \mathrm{~mm}$

- Beam size of the structure is of $450 \mathrm{mmx} 600 \mathrm{~mm}$

- Slab thickness of the structure is of $125 \mathrm{~mm}$

- Flat slab thickness $200 \mathrm{~mm}$

- $\quad$ Size of drop $2500 \mathrm{~mm} \times 2500 \mathrm{~mm}$

- Thickness of drop is $350 \mathrm{~mm}$

- Shear wall thickness $230 \mathrm{~mm}$

- Concrete bracing is of $300 \mathrm{~mm} \times 450 \mathrm{~mm}$.

The following figure shows the geometry of plan with material and section properties 


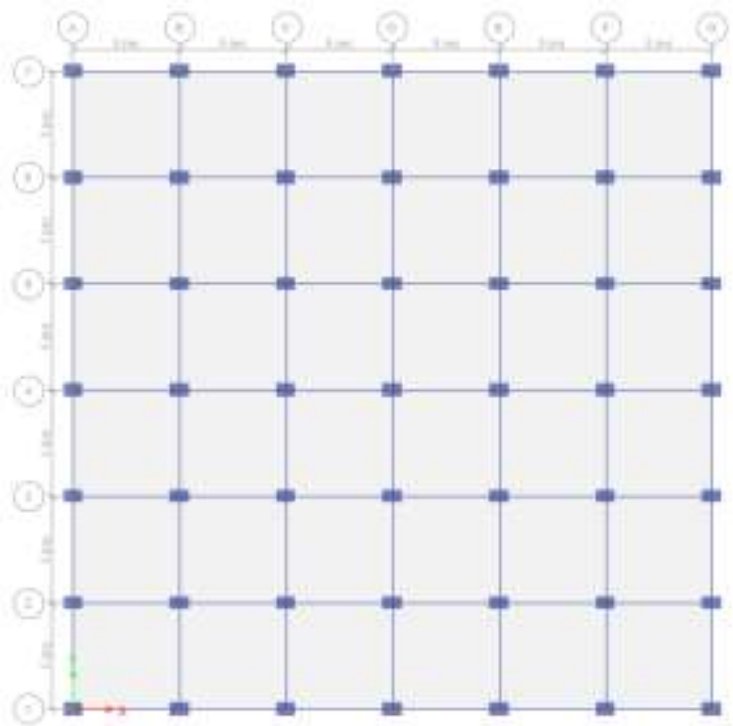

Fig 7:-Plan of Grid Slab Structure

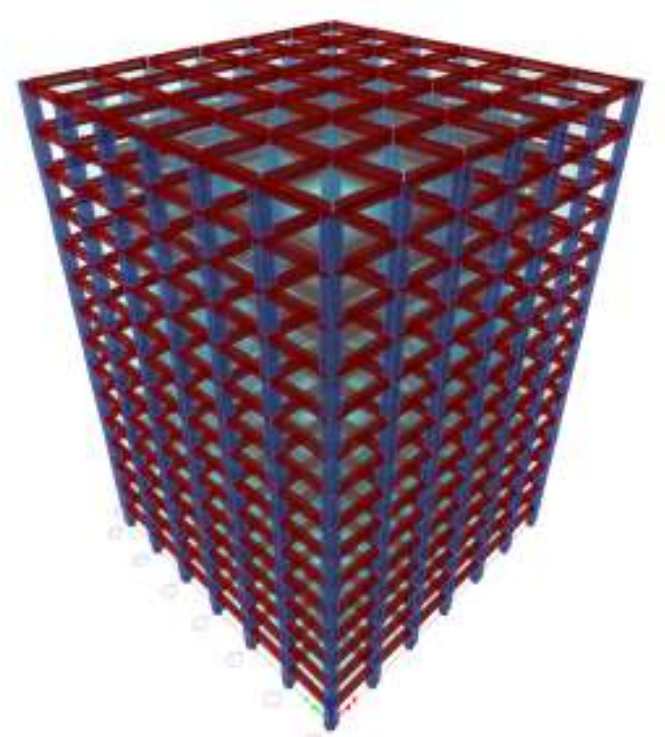

Fig 8:-3D View of Grid Slab Structure

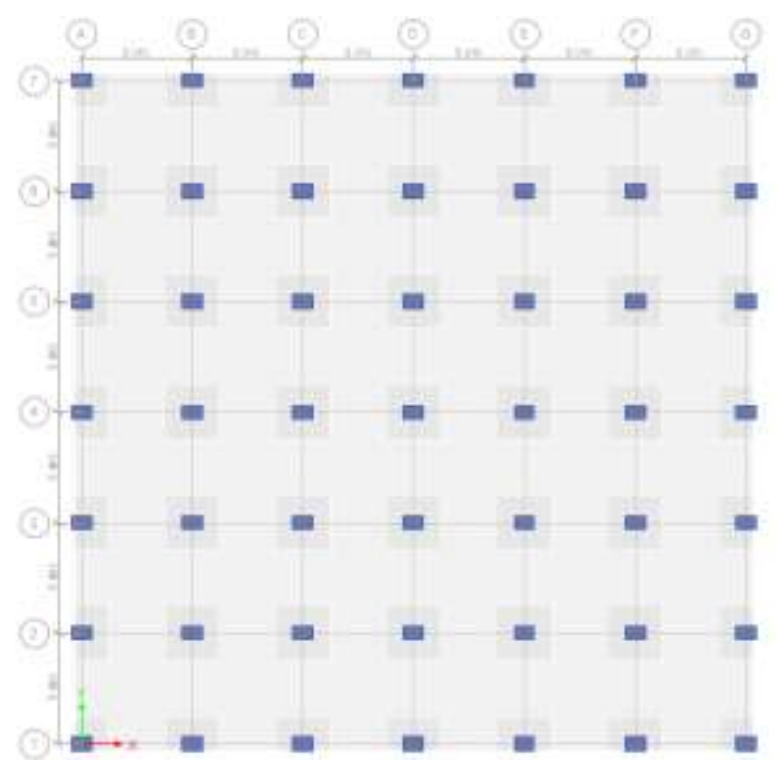

Fig 9:-Plan of Flat Slab Structure

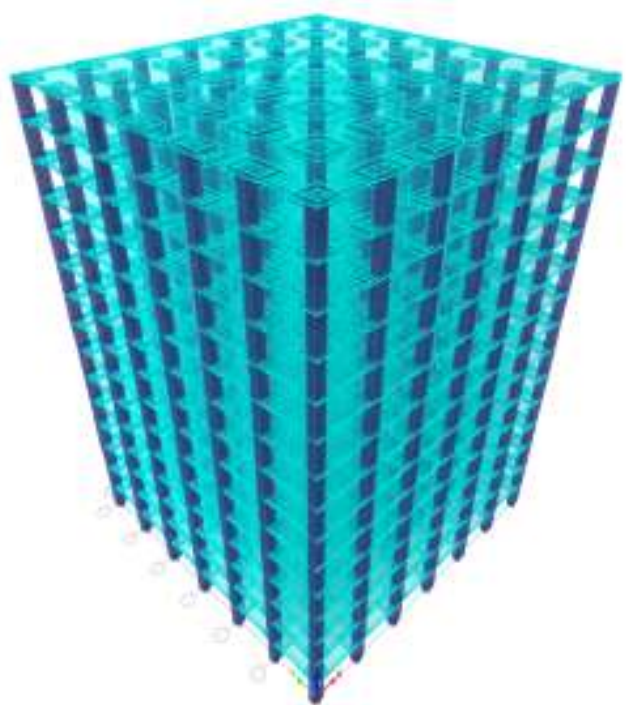

Fig 10:-3D View of Flat Slab Structure

\section{ANALYSIS OF THE STRUCTURES}

The loading of the building is considered as per following calculation

1. Dead Loads

$\checkmark$ Self-weight of the structure is automatically taken by software itself.

$\checkmark \quad$ The self-weight of grid slab $=.125 \times 1 \times 1 \times 25=$ $3.125 \mathrm{kN} / \mathrm{m} 2$

$\checkmark \quad$ Load due to floor finish $=1 \mathrm{kN} / \mathrm{m} 2$

$\checkmark \quad$ Load due to Wall $=0.23 \times 20 \times 3=13.8 \mathrm{kN} / \mathrm{m} 2$

$\checkmark \quad$ Weight of slab having thickness $250 \mathrm{~mm}=0.25 \mathrm{x}$ $25=6.25 \mathrm{kN} / \mathrm{m} 2$

2. Live Loads

$\checkmark \quad$ The live load assume $3 \mathrm{kN} / \mathrm{m} 2$ on floors

3. Loads Combinations

$\checkmark$ As per the IS codes load combinations were generated based on concrete frame design itself by software

4. Earthquake Loads

$\checkmark$ In this present work "response spectrum method" of analysis is used.

$\checkmark$ As per "IS 1893" code book seismic loading is assign to the structure.

$\checkmark \quad$ This load is taken in to account by specifying the zone and soil type in which structure is assumed to be located.

$\checkmark$ Importance factor: - 1 .

$\checkmark$ Response reduction factor: - 5 .

$\checkmark$ Damping ratio 0.05

\subsection{Types of Cases Used For Analysis of Structures}

The different cases are considered to study the seismic behavior of both the slab with and without masonry infills. As previously mentioned two zones are considered with soil type II with different masonry such as shear wall and bracing. From the earlier papers concluded that building with shear wall along periphery shows good response against horizontal loading similarly in case of concrete bracing also the X-type bracing applied on vertical faces of 
building shows better improvement in resisting lateral forces. So in this present work also will take shear wall along periphery and X-type bracing on all four side of building with different zones in medium soil. Thus in this way total 18 number of model will analyzed to study the different forces acting on structures.The following model with description as written below with same soil condition i.e. soil II

Case 1) Grid slab structure without masonry in zone II.

Case 2) Grid slab structure in zone II with shear wall.

Case 3) Grid slab structure in zone II with X-type bracing.

Case 4) Grid slab structure without masonry in zone III.

Case 5) Grid slab structure in zone III with shear wall.

Case 6) Grid slab structure in zone III with X-type bracing.

Case 7) Flat slab with drop structure without masonry in zone II.

Case 8) Flat slab with drop structure in zone II with shear wall.

Case 9) Flat slab with drop structure in zone II with X-type bracing.

Case 10)Flat slab with drop structure without masonry in zone III.

Case 11)Flat slab with drop structure in zone III with shear wall.

Case 12)Flat slab with drop structure in zone III with X-type bracing.

Case 13)Flat slab without drop structure without masonry in zone II.

Case 14)Flat slab without drop structure in zone II with shear wall.

Case 15)Flat slab without drop structure in zone II with Xtype bracing.

Case 16)Flat slab without drop structure without masonry in zone III.

Case 17)Flat slab without drop structure in zone III with shear wall.

Case 18)Flat slab without drop structure in zone II with Xtype bracing.

Following figures shows the model of different cases done in ETABs software.-

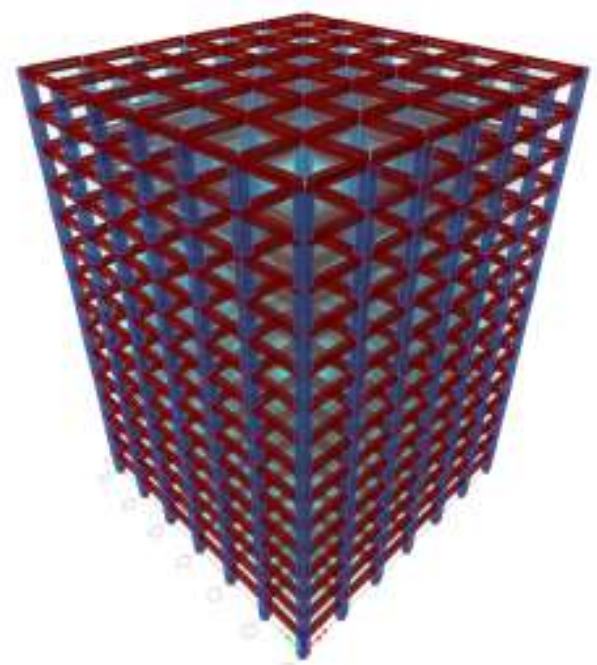

Fig 11:-Model-1 Grid slab structure without masonry

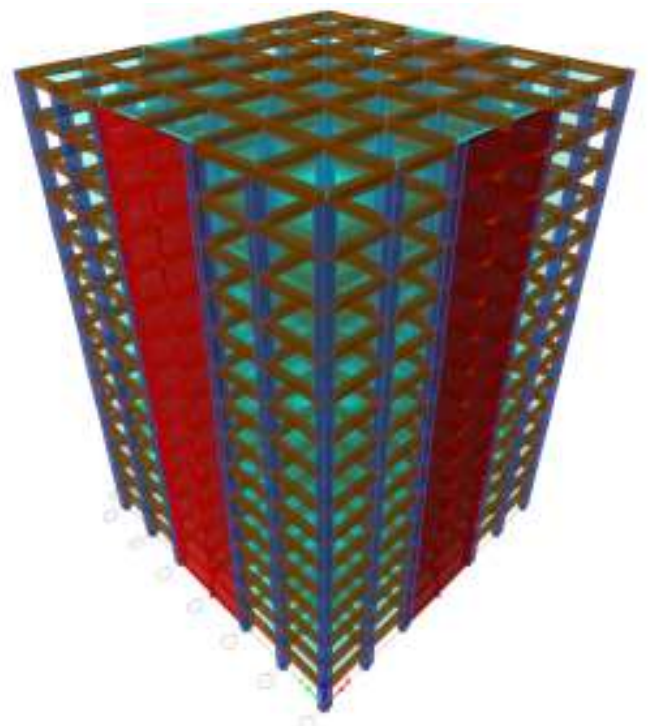

Fig 12:-Model-2 Grid slab structure with shear wall

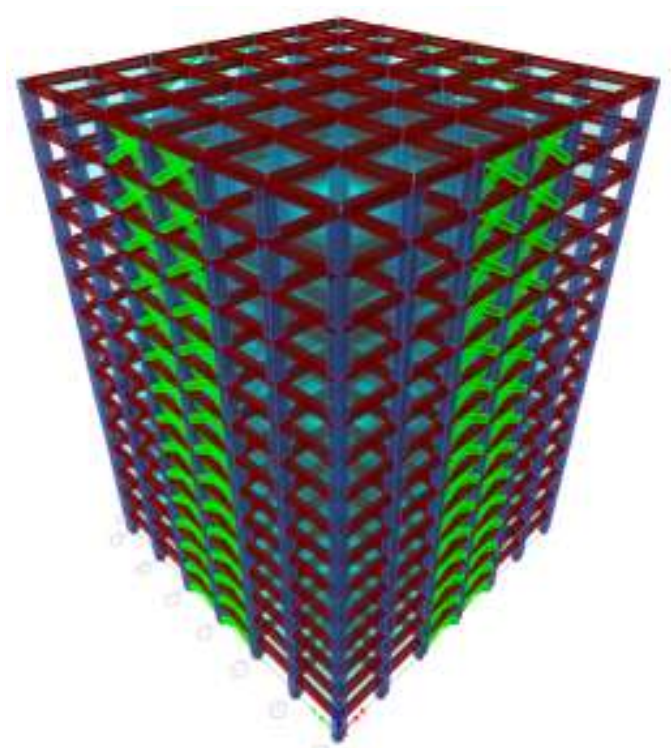

Fig 13:-Model-3 Grid slab structure with bracing

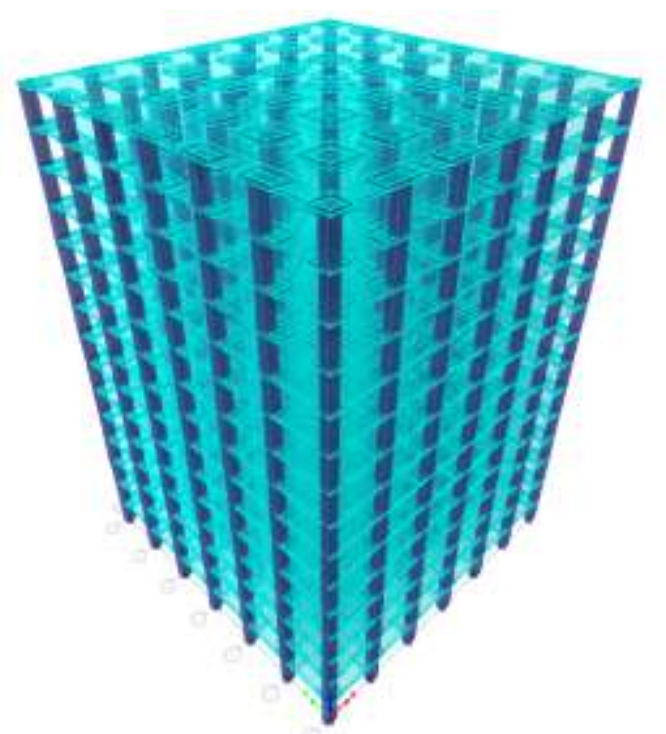

Fig 14:-Model-4 Flat Slab structure without masonry 


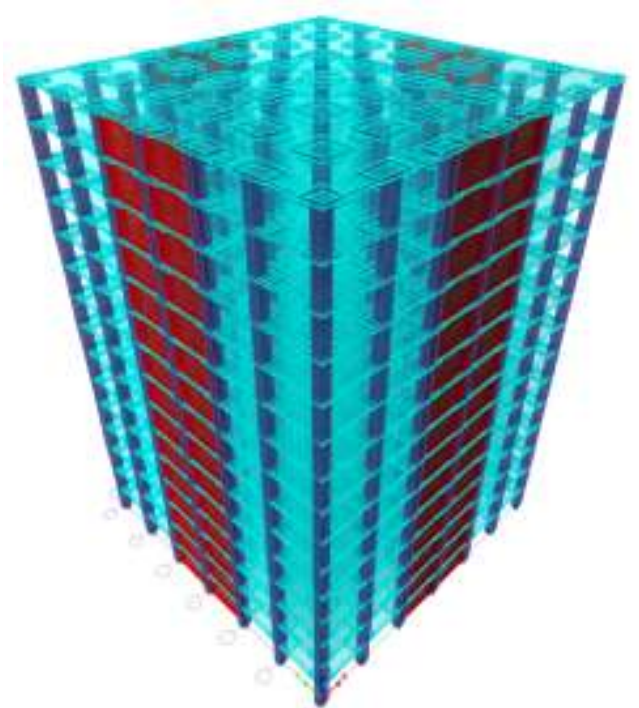

Fig 15:-Model-5 Flat slab structure with shear wall.

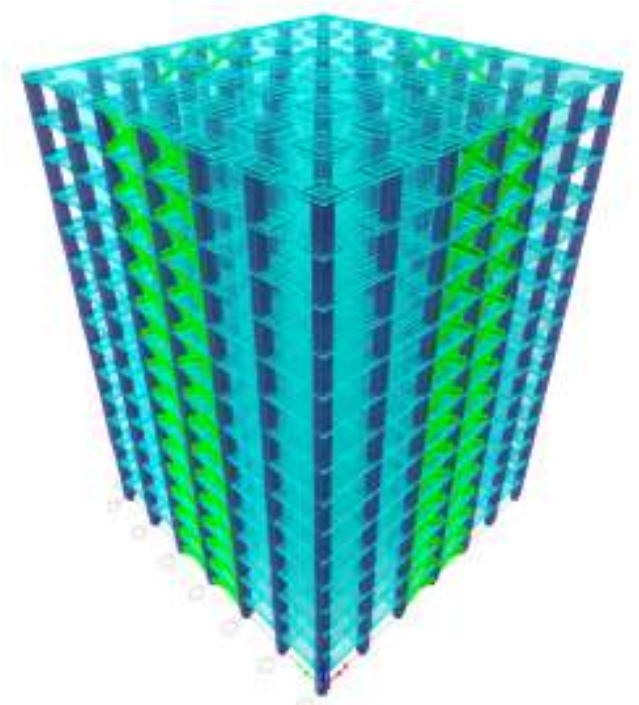

Fig 16:-Model-6 Flat slab with bracing

Similarly,

$>$ Model-7 Flat slab without drop without masonry.

$>$ Model-8 Flat slab without drop with shear wall.

$>$ Model-9 Flat slab without drop with bracing

\section{RESULTS AND DISCUSSION}

\subsection{Time Period}

Maximum displacement is considered for comparison of grid slab structure with the flat slab with drop structure in zone III and zone IV with the soil type II. From the results of analysis of different models represented in below column graphs, so it can observed that the storey displacement is maximum at the top storey of structures. And displacement is maximum in flat slab with drop compare to grid slab with and without infills in both zones, but little more in zone IV than zone III. The structure with infills are considerably less displacement than without infills. Structure with shear wall adequately reduces displacement in grid slab as well as in flat slab with drop.Method 1
Table -1: Max Displacement in zone III for different types of buildings

\begin{tabular}{|l|l|l|l|}
\hline \multicolumn{3}{|l|}{ DISPLACEMENT (mm) } \\
\hline \multicolumn{3}{|l|}{ Comparison Zone III Soil 2 } & With \\
\hline Model & $\begin{array}{l}\text { Without } \\
\text { Infill }\end{array}$ & $\begin{array}{l}\text { Shear } \\
\text { Wall }\end{array}$ & $\begin{array}{l}\text { With } \\
\text { Bracing }\end{array}$ \\
\hline $\begin{array}{l}\text { Grid Slab } \\
\text { Structure }\end{array}$ & 8.284 & 6.086 & 6.857 \\
\hline $\begin{array}{l}\text { Flat slab with } \\
\text { Drop } \\
\text { structure }\end{array}$ & 9.791 & 6.759 & 7.69 \\
\hline
\end{tabular}

Table -2: Max Displacement in zone IV for different types of buildings

\begin{tabular}{|l|l|l|l|}
\hline \multicolumn{4}{|l|}{ DISPLACEMENT (mm) } \\
\hline Comparison Zone IV Soil 2 \\
\hline Model & $\begin{array}{r}\text { Witho } \\
\text { ut Infill }\end{array}$ & $\begin{array}{l}\text { With } \\
\text { Shear } \\
\text { Wall }\end{array}$ & $\begin{array}{l}\text { With } \\
\text { Bracing }\end{array}$ \\
\hline $\begin{array}{l}\text { Grid Slab } \\
\text { Structure }\end{array}$ & 12.426 & 9.129 & 10.286 \\
\hline $\begin{array}{l}\text { Flat slab with } \\
\text { Drop structure }\end{array}$ & 14.686 & 10.405 & 11.536 \\
\hline
\end{tabular}

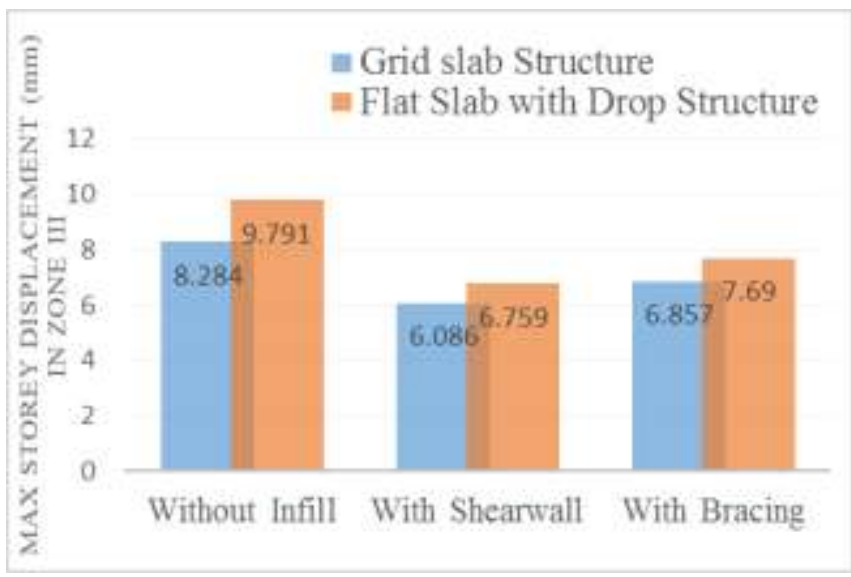

Chart -1: Max Storey Displacement in zone III for different types of structures with and without masonry infills

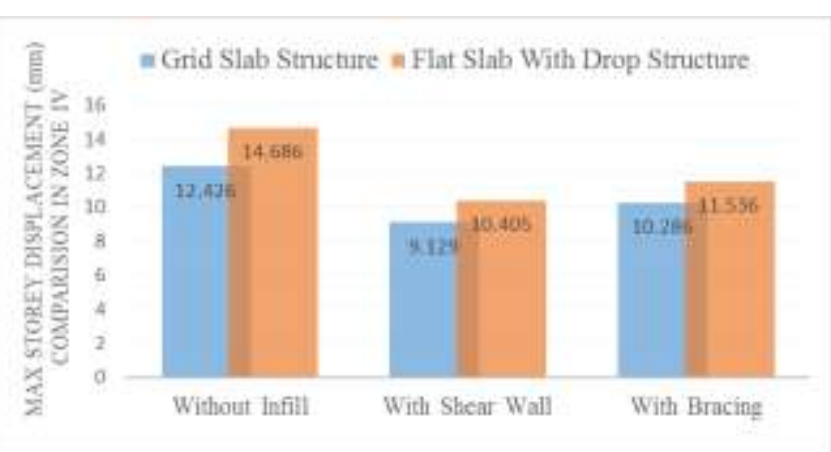

Chart -2: Max Storey Displacement in zone IV for different types of structures with and without masonry infills 


\subsection{Time Period}

Time period of different structures is maximum at mode 1 respectively. The results of different structures have been shown in below graphs. From that it can be observed time period of structures without infills is significantly more compare to structure with infills. Time period of grid slab is less in compare with flat slab with and without drop with and without infills structures i.e. $14.57 \%$ and $47 \%$ less in structures without infills and $10.15 \%$ and $29.10 \%$ less in structure with shear wall and $13.25 \%$ and $28.60 \%$ less in structure with bracing, but flat slab without drop having more time period. But in case of structure with infills specifically with shear wall time period is considerably less compare with structure with bracing i.e. difference of 17 to $20 \%$.

Table -3: Max Displacement in zone III for different types of buildings

\begin{tabular}{|l|l|l|l|}
\hline \multicolumn{3}{|l|}{ MAX TIME PERIOD } \\
\hline \multicolumn{3}{|l|}{ Comparison Zone IV Soil 2 } \\
\hline Model & $\begin{array}{c}\text { Without } \\
\text { Infill }\end{array}$ & $\begin{array}{l}\text { With } \\
\text { Shear } \\
\text { Wall }\end{array}$ & $\begin{array}{l}\text { With } \\
\text { Bracing }\end{array}$ \\
\hline Grid Slab Structure & 1.237 & 0.77 & 0.936 \\
\hline $\begin{array}{l}\text { Flat slab with Drop } \\
\text { structure }\end{array}$ & 1.448 & 0.857 & 1.036 \\
\hline $\begin{array}{l}\text { Flat slab without } \\
\text { Drop structure }\end{array}$ & 2.334 & 1.035 & 1.311 \\
\hline
\end{tabular}

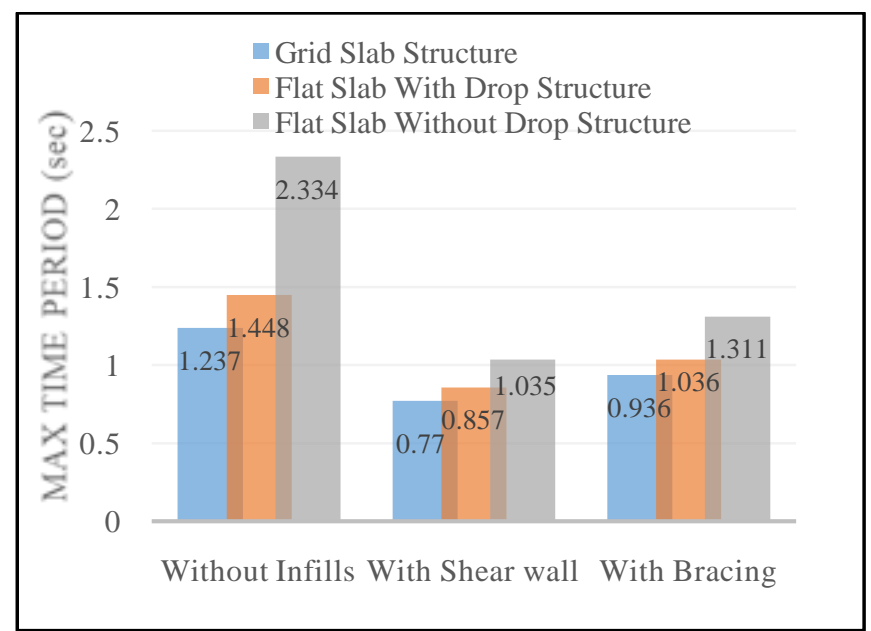

Chart -3: Max Time period in zone IV for different types of structures with and without masonry infills.

\subsection{Storey Base Shear}

The results storey base shear of different building is shown in below table with graph below. From graph it can be observed that the base shear is maximum at the plinth level for all different types of structures. And also base shear of grid slab structure is maximum in comparison with flat slab with and without drop structures. Flat slab with-no drop having considerably less base shear than other two slab system. Base shear is more in zone IV than zone III in all the different structures. Infills structures having more storey base shear than structures without infills i.e. $22 \%$ to $37 \%$. In case of structures with shear wall having more storey base shear than structures with bracing for all types of structures i.e. the difference varies $13 \%$ to $18 \%$.

Table -4: Max Base Shear in zone III for different types of buildings

\begin{tabular}{|l|l|l|l|}
\hline \multicolumn{3}{|l|}{ STOREY BASE SHEAR (KN) } \\
\hline Comparison Zone III Soil 2 \\
\hline Model & $\begin{array}{l}\text { Without } \\
\text { Infill }\end{array}$ & $\begin{array}{l}\text { With Shear } \\
\text { Wall }\end{array}$ & $\begin{array}{l}\text { With } \\
\text { Bracing }\end{array}$ \\
\hline $\begin{array}{l}\text { Grid Slab } \\
\text { Structure }\end{array}$ & 2107.164 & 3113.668 & 2701.97 \\
\hline $\begin{array}{l}\text { Flat slab with } \\
\text { Drop structure }\end{array}$ & 1801.334 & 2848.58 & 2398.02 \\
\hline $\begin{array}{l}\text { Flat slab without } \\
\text { Drop structure }\end{array}$ & 1154.682 & 2258.051 & 1837.906 \\
\hline
\end{tabular}

Table -5: Max Base Shear in zone IV for different types of buildings

\begin{tabular}{|l|l|l|l|}
\hline \multicolumn{3}{|l|}{ STOREY BASE SHEAR (KN) } \\
\hline Comparison Zone IV Soil 2 \\
\hline Model & $\begin{array}{c}\text { Without } \\
\text { Infill }\end{array}$ & $\begin{array}{l}\text { With Shear } \\
\text { Wall }\end{array}$ & $\begin{array}{l}\text { With } \\
\text { Bracing }\end{array}$ \\
\hline $\begin{array}{l}\text { Grid Slab } \\
\text { Structure }\end{array}$ & 3160.746 & 4670.502 & 4052.955 \\
\hline $\begin{array}{l}\text { Flat slab with } \\
\text { Drop structure }\end{array}$ & 2702.002 & 4272.871 & 3597.030 \\
\hline $\begin{array}{l}\text { Flat slab without } \\
\text { Drop structure }\end{array}$ & 1732.029 & 3387.007 & 2756.859 \\
\hline
\end{tabular}

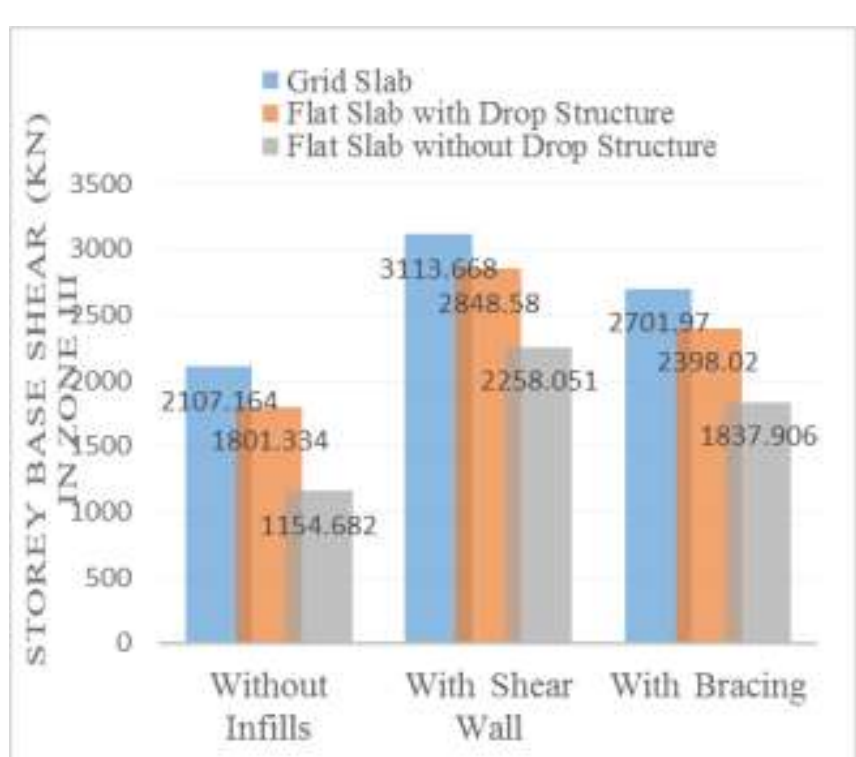

Chart -4: Max Base shear in zone III for different types of structures with and without masonry infills 


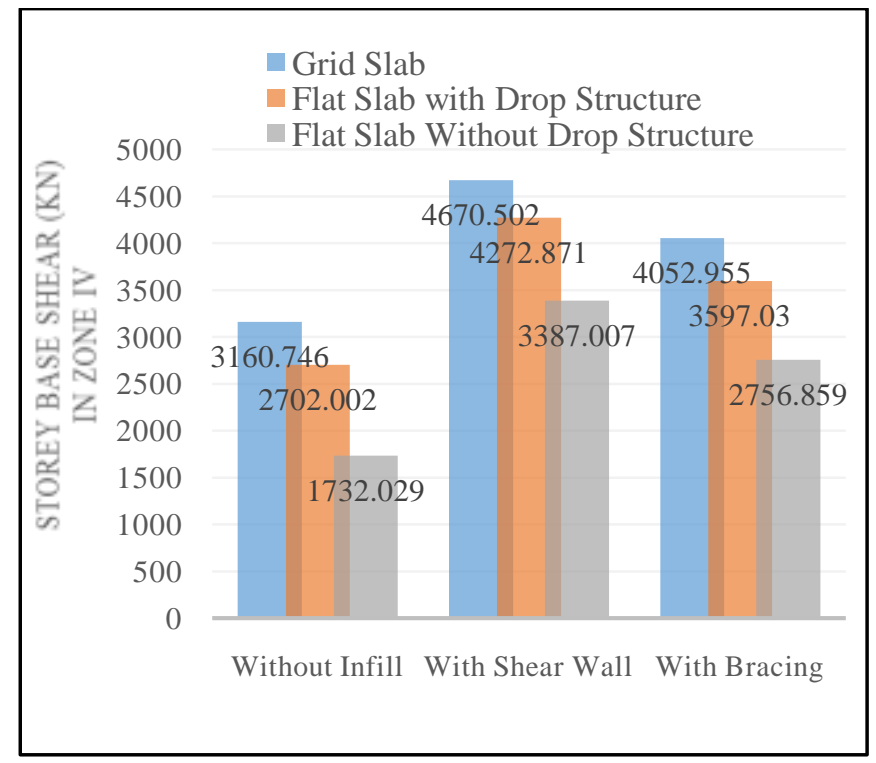

.Chart -5: Max Base shear in zone IV for different types of structures with and without masonry infills

\subsection{Storey Drift}

Drift value can be said as the difference between displacements of on storey compare to other storey. The analysis results have been displayed in table below respectively for different types of buildings in different zones. From the bar graph it can be noticed that storey drift values of different types of buildings are within the permissible limit as per IS-1893-2002 code provision i.e. $0.4 \%$ of the floor height. For this present project floor height is $3000 \mathrm{~mm}$, therefore limited drift value is $12 \mathrm{~mm}$. The drift value of grid slab is less compare to flat slab with and without drop with infills and without infills in both zones. Flat slab without drop having more drift value. The drift value in zone IV is more compare to zone III for all the different types of buildings. The drift value of structure with shear wall having considerably less in compare with the structure with bracing for all types of different structure in both zones i.e. $13 \%$ to $15 \%$ difference

Table -6: Max Storey Drift in zone III for different types of buildings

\begin{tabular}{|l|l|l|l|}
\hline \multicolumn{4}{|l|}{ MAX STOREY DRIFT } \\
\hline Comparison Zone III Soil 2 \\
\hline Model & $\begin{array}{c}\text { Without } \\
\text { Infill }\end{array}$ & $\begin{array}{l}\text { With } \\
\text { Shear } \\
\text { Wall }\end{array}$ & $\begin{array}{l}\text { With } \\
\text { Bracing }\end{array}$ \\
\hline $\begin{array}{l}\text { Grid Slab } \\
\text { Structure }\end{array}$ & 0.813 & 0.495 & 0.576 \\
\hline $\begin{array}{l}\text { Flat slab with } \\
\text { Drop structure }\end{array}$ & 0.966 & 0.549 & 0.633 \\
\hline $\begin{array}{l}\text { Flat slab without } \\
\text { Drop structure }\end{array}$ & 1.56 & 0.708 & 0.837 \\
\hline
\end{tabular}

Table -7: Max Storey Drift in zone IV for different types of buildings

\begin{tabular}{|l|l|l|l|}
\hline \multicolumn{4}{|l|}{ MAX STOREY DRIFT } \\
\hline Comparison Zone IV Soil 2 \\
\hline Model & $\begin{array}{l}\text { With } \\
\text { out } \\
\text { Infill }\end{array}$ & $\begin{array}{l}\text { With } \\
\text { Shear } \\
\text { Wall }\end{array}$ & $\begin{array}{l}\text { With } \\
\text { Bracing }\end{array}$ \\
\hline Grid Slab Structure & 1.218 & 0.741 & 0.864 \\
\hline $\begin{array}{l}\text { Flat slab with Drop } \\
\text { structure }\end{array}$ & 1.449 & 0.825 & 0.948 \\
\hline $\begin{array}{l}\text { Flat slab without } \\
\text { Drop structure }\end{array}$ & 2.34 & 1.062 & 1.254 \\
\hline
\end{tabular}

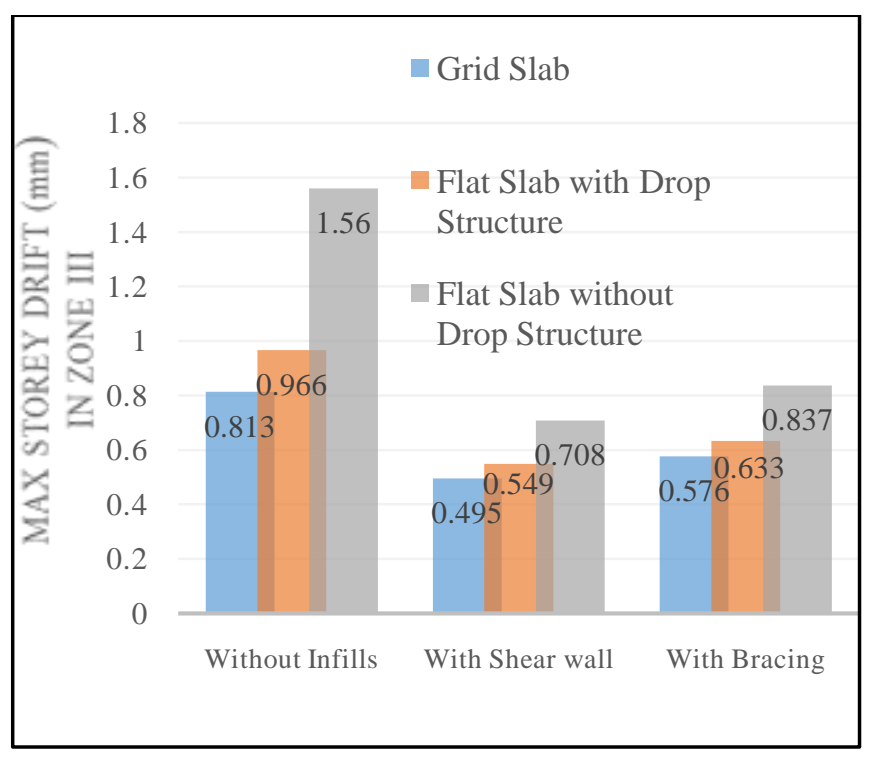

Chart -6: Max Storey Drift in zone III for different types of structures with and without masonry infills

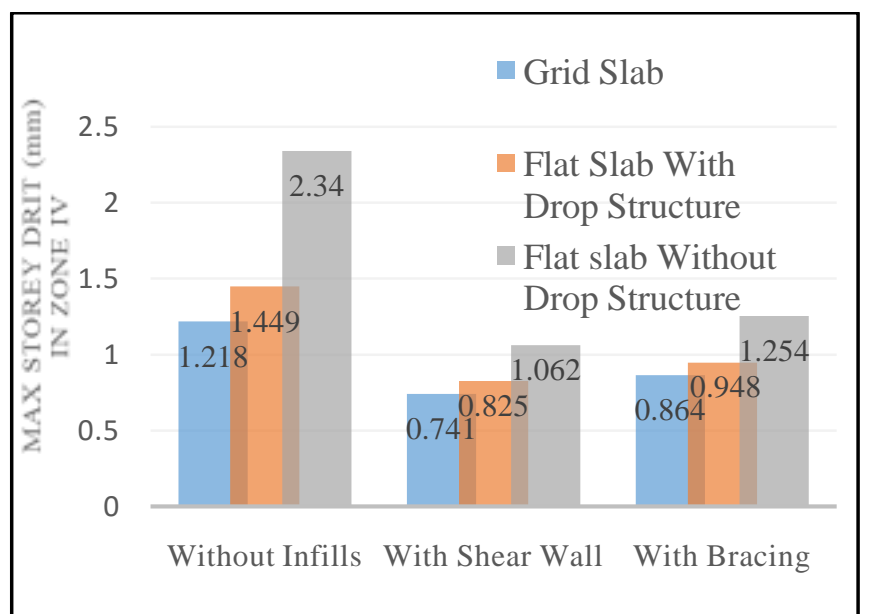

Chart -7: Max Storey Drift in zone IV for different types of structures with and without masonry infills

\section{CONCLUSION}

In this project the seismic analysis is carried out to study the comparison between flat slab with and without drop structures and grid slab structures with and without masonry infills under two different zones for various parameters and from the above results it can be concluded that 
$\checkmark$ Maximum displacement is observed in flat slab with drop compare to grid slab with and without infills in both zones, but deflection is more in zone IV than zone III. The structure with infills are considerably less displacement than without infills. Structure with shear wall adequately reduces displacement in grid slab as well as in flat slab with drop.

$\checkmark$ Maximum Time period of grid slab is less in compare with flat slab with and without drop with and without infills structures in zone IV. Structures without infills having significantly more time period compare to structure with infills. But structures with shear wall having 17 to $20 \%$ less time period compare with bracing structure.

$\checkmark$ Grid slab structures possess maximum base shear in comparison with flat slab with and without drop in both zones. Infills structures having $22 \%$ to $37 \%$ more storey base shear than structures without infills. Shear wall having more storey base shear than structures with bracing i.e. the difference varies $13 \%$ to $18 \%$.

$\checkmark$ Storey drift values of different types of buildings are within the permissible limit as per IS-1893-2002 code provision i.e. $0.4 \%$ of the floor height. . The drift value in zone IV is more compare to zone III for all the different types of buildings. The structure with shear wall having $13 \%$ to $15 \%$ less drift value in compare with the bracing structure.

$\checkmark \quad$ The building with shear wall along periphery act as infills in both the zones better performance against the effect of horizontal loads compare to concrete bracings.

\subsection{Scope for Future Study}

$\checkmark \quad$ To investigate the behaviour of grid slab and flat slab with different steel bracing connection.

$\checkmark \quad$ This study is carried out by considering regular building further study can be carried out by taking irregular buildings.

$\checkmark \quad$ To study the behaviour of different slab by considering composite steel sections.

$\checkmark$ In this present work the linear dynamic analysis is carried out further study can be possible by considering non-linear analysis example push over analysis.

\section{ACKNOWLEDGEMENT}

The study could not have been completed without the aid and assistance of our dear Principal. We would like to thank him for all his effort in guiding us. We would like to thank all the authors of various journals and books for enlightening us with their knowledge. We are grateful to our family, friends and the Department of Civil Engineering.

\section{REFERENCES}

[1] [Navyashree K and Sahana T S (2014), "Use of flat slabs in multi-storey commercial building situated in high seismic zone", Vol.03, No. 08, IJRET: International Journal of Research in Engineering and Technology.

[2] Makode R K, Akhtar S and Batham G (2014), "Dynamic analysis of multi-storey RCC building frame
With flat slab and grid slab", Al Int. Journal of Engineering Research and Applications, Vol. 4, No. 2, Version 1, pp. 416-420.

[3] Patwari K G, Kalurkar L G (2016), “Comparative study of RC flat slab and shear wall with conventional framed structure in high rise building", Volume No. 05, International Journal of Engineering Research.

[4] AnujaWalvekar, Jadhav H S (2015), "Parametric study of flat slab building with and without shear wall to seismic performance", Vol.04, No. 04, IJRET: International Journal of Research in Engineering and Technology.

[5] Sharad P. Desa, Swapnil B. Cholekar (2013), "Seismic behaviour of flat slab framed structure with and without masonry infill wall", Vol.02, No. 07, IJRET: International Journal of Research in Engineering and Technology.

[6] M Vinod Kumar Reddy, Dr. Vaishali G Ghorpade (2014), "Comparitive study of aeismic analysis between conventional and flat Slab with drop and without drop Framed structures with different masonary infills", Vol.03, No. 10, IJRET: International Journal of Research in Engineering and Technology.

[7] Umesh.R.Biradar, ShivarajMangalgi (2014), "Seismic response of reinforced concrete structure by using different bracing system", Vol.03, No. 09, IJRET: International Journal of Research in Engineering and Technology.

\section{BIOGRAPHIES}

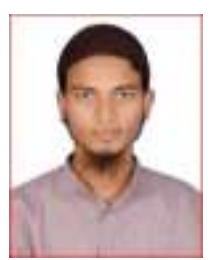

Mr., MOHAMMED FATIR Obtained his bachelor of engineering (Civil Engineer) fromAnjuman Institute of Technology and Management and Master in Technology (structural engineer) from secab institute of engineering and technology vijayapur.

Mr.M.H.KOLHAR presently he is working as professor and head of P.G civil department in secab institute of engineering and technology vijayapur India

Ms. ANJUM ALGUR presently she is working as Assistant Professor in Civil Department ofSecab Institute of Engineering and Technology Vijayapur India 